\title{
Short Communication: The detection of Plasmodium in mosquitoes from Sumba and Sorong districts, Indonesia
}

\author{
MUNIRAH MUNIRAH ${ }^{1}$, ISRA WAHID ${ }^{2}$, FIRDAUS HAMID ${ }^{3}$, SITTI WAHYUNI ${ }^{2, \bullet}$ \\ ${ }^{1}$ Doctoral Program in Medical Faculty, Universitas Hasanuddin. Jl. Perintis Kemerdekaan 10, Tamalanrea, Makassar 90245, South Sulawesi, Indonesia \\ ${ }^{2}$ Department of Parasitology Faculty of Medicine, Universitas Hasanuddin. Jl. Perintis Kemerdekaan 10, Tamalanrea, Makassar 90245, South Sulawesi, \\ Indonesia. Tel.: +62-411-586010, Fax.: +62-411-586297, `email: sittiwahyuni@ gmail.com \\ ${ }^{3}$ Department of Microbiology, Faculty of Medical, Universitas Hasanuddin. Jl. Perintis Kemerdekaan 10, Tamalanrea, Makassar 90245, South Sulawesi, \\ Indonesia
}

Manuscript received: 19 October 2020. Revision accepted: 13 June 2021.

\begin{abstract}
Munirah M, Wahid I, Hamid F, Wahyuni S. 2021. Short Communication: The detection of Plasmodium in mosquitoes from Sumba and Sorong districts, Indonesia. Biodiversitas 22: 2680-2684. Malaria is heading for elimination in 2030, but the disease remains prevalent in Indonesia. Therefore, this study aimed to determine a vector other than Anopheles that is potentially responsible for malaria transmission in the country's endemic areas. The mosquitoes were trapped by Kelambu trap, collected using a mouth aspirator, and stored in a tube containing silica gel. They were also examined microscopically following O'Connor identification keys, and Nested PCR was used to detect Plasmodium DNA. The number of mosquitoes collected from two areas was 1.336. In Sumba (Gaura village) district, 493 mosquitoes were captured, and the dominant genus was Anopheles (58.6\%), followed by Culex (31\%), Armigeres (9.9\%), Aedes (0.2\%), and Lutzia (0.2\%). Among 843 mosquitoes collected from Sorong (Aimas), Culex was $98.9 \%$, followed by Aedes $(0.8 \%)$ and Anopheles $(0.2 \%)$. The result of nested PCR found two An. sundaicus from Sumba carried Plasmodium which belongs to P. falciparum and $P$. vivax species $(0.14 \%)$. Although we did not detect the presence of Plasmodium in mosquitoes other than the genus Anopheles, in this study, we found Anopheles species that have never previously been reported from the area, namely An. bailey and An. barbirostris from Papua and An. nivipes in West Sumba.
\end{abstract}

Keyword: Anopheles, malaria, nested PCR, Plasmodium, vector

\section{INTRODUCTION}

Malaria is caused by Plasmodium protozoan, and the total cases have reached 228 million globally, with 405,000 deaths in 2018 (WHO 2019). East Nusa Tenggara (Sumba) and West Papua are the areas having the highest prevalence, with $7.04 \%$ and $31.29 \%$ Annual Parasites Incidence (API), respectively (Indonesian Ministry of Health 2016). Attempts have been made to eliminate the parasite, including mass treatment, breeding site suppression, application of insecticide net (PATH Malaria Centre 2014), and vector surveillance (Indonesian Ministry of Health 2014). However, API's change is still not satisfactory and those methods need expansion to ensure malaria is eliminated.

The high prevalence is inseparable from the existence of Anopheles, and the species responsible for spreading malaria is not the same in all areas. In America, the typical vector is An. freeborni Aitken, but it is An. atroparvus van Thiel in the Middle East and Europe, An. arabiensis Patton in Africa and An. barbirostris van der Wulp in Asia. In Indonesia, the dominant Plasmodium vector differs across all Islands (Sinka et al. 2012), for instance, it is An. farauti in Jayapura (Elyazar 2013), An. balabacensis in Kalimantan (St. Laurent et al. 2016) and An. barbirostris in Sulawesi (Nurdin et al. 2003; Veridiana et al. 2019).
Importantly, Culex is the mosquito genus first known as an intermediate host of lymphatic filariasis (Ogoma et al. 2010). Afterward, Aedes, Anopheles, and Mansonia also transmit it (WHO 2013), while malaria cases likely likewise encounter a related situation.

Mutations are changes that occur in the genetic material and it can be passed to heredity (Campbell et al. 2014; Campbell et al. 2015). The mutation allows the parasite to adapt to the host, and it tends to also benefit either or both of them (M'Gonigle 2009). In terms of their interaction, the mutation rate is determined by genome size which is shorter in parasites than the host, therefore causing higher mutation frequency (McDew-White et al. 2019). This condition makes the parasite, known as a pathogenic microorganism, adapt to a new host when exposure occurs continuously (Mackinnon and Marsh 2010). Global warming also plays a role in adding a new host for the parasite (Mills et al. 2010). Stress due to heating causes a mutation in both unicellular or multicellular organisms, which allows them to survive and pass their ability to the next generation for adaptation to the new host environment (Berger et al. 2017). Based on the personal discussion with the head of the communication disease from Sorong Health Office, the survey conducted in one of the district's villages during the malaria outbreak found no Anopheles larvae. The theory and case raise the query of whether there is 
another genus that potentially carries the Plasmodium parasite. This study aims to detect Plasmodium as a vector of malaria in female mosquitoes from various genera in malaria-endemic areas.

\section{MATERIALS AND METHODS}

\section{Mosquitos collection}

Female mosquitoes were collected from the residential area of Gaura Village, South West Sumba District of East Nusa Tenggara, Indonesia (October 2018), and Aimas, Sorong District of West Papua, Indonesia (August 2019). Provincial health offices determined those two areas have the highest API in the districts. Due to the absence of electricity to make a light trap, mosquitoes were collected using Kelambu and the cow available in the area were used as the bait. Kelambu modified from previous studies (Davidson et al. 2019). The mosquito collection in Gaura and Aimas was carried out at 7 different locations, respectively, in one-night collection was done only in one location. Mosquitoes in the Kelambu were collected every hour, from 7 p.m until 1 a.m, using a mouth aspirator. They were placed in $1.5 \mathrm{ml}$ tubes containing silica gel to prevent mold growth and structural damage of the vector, which absorbs moisture to reduce the tube's humidity. Microscopic mosquito identification was performed by following O'Connor's key (O'Connor et al., 1981). Especially for Anopheles, the species were validated by PCR using ITS2 primer (Weeraratne et al. 2017), and the product was sent to Genetica Science, Singapore, for sequencing. For Plasmodium DNA identification, the headthorax was separated from the abdomen by a fine needle, and both parts were stored in different tubes.

\section{DNA Extraction}

One to five head-thorax parts of mosquitoes from the same species were pooled in a $1.5 \mathrm{ml}$ microtube and macerated using disposable Teflon pestles, while the DNA was extracted using the TIANamp Genomic kit. The head- thorax was smashed in a $1.5 \mathrm{ml}$ tube, $20 \mathrm{ml}$ proteinase $\mathrm{K}$ was added, then vortexed and incubated at $56^{\circ} \mathrm{C}$ ( 3 hours). Two hundred $\mu 1$ of buffer GB was added to the tube, mixed thoroughly, vortexed before incubation at $70^{\circ} \mathrm{C} \quad(10$ minutes) and then centrifuged. Another $200 \mu \mathrm{l}$ ethanol (96$100 \%$ ) was poured into the 1.5 tubes, mixed thoroughly, vortexed, and then centrifuged. The mixture from the 1.5 tubes was moved to the spin column which was then placed onto the collection tube. Five hundred $\mu 1$ of buffer GD was added to the spin column, centrifuged at $12000 \mathrm{rpm}(30$ seconds), discarded the flow-through, and then placed onto the collection tube. Six hundred $\mu$ l of buffer PW was added and processed as before and repeated once again, which was centrifuged at $12000 \mathrm{rpm}$ for 2 minutes to dry the membrane completely. The spin-column was put into a 1.5 $\mathrm{ml}$ tube and $100 \mu \mathrm{l}$ of buffer TE was pipetted to the membrane's center. It was incubated at room temperature for 5 minutes and then centrifuged as the previous, followed by storing the purified DNA at $-20^{\circ} \mathrm{C}$. When the PCR product indicated Plasmodium in the head-thorax pool, the corresponding mosquito's DNA from the abdomen pools was extracted separately to determine the number of positive species and then stored at $-20^{\circ}$ for further analysis.

\section{DNA Amplification}

Polymerase chain reaction (PCR) Thermociclador T100 Biorad was used to detect Plasmodium in the mosquitoes. Nested PCR was performed using three pairs of primers, namely rPLU5: 5'-CCTGTTGTTGCCTTAAACTTC-3' and rPLU6: 5'-TTAAAATTGTTGCAGTTAAAACG-3' for Plasmodium species in the nested 1. Furthermore, the other two were rVIV1: 5'-CGCTTCTAGCTTAATCCA CATAACTGATAC-3' and rVIV2: 5'-ACTTCCAAGCCG AAGCAAAGAAAGTCCTTA-3' for $P l$. vivax in nested 2, rFAL1: 5'-TTAAACTGGTTTGGGAAAACCAAATATATT3' and rFAL2: 5'-ACACAATGAACTCAATCATGACTA CCCGTC-3' for $P l$. falciparum in nested 2, as previously described (Snounou et al. 1993; Singh et al. 2013).

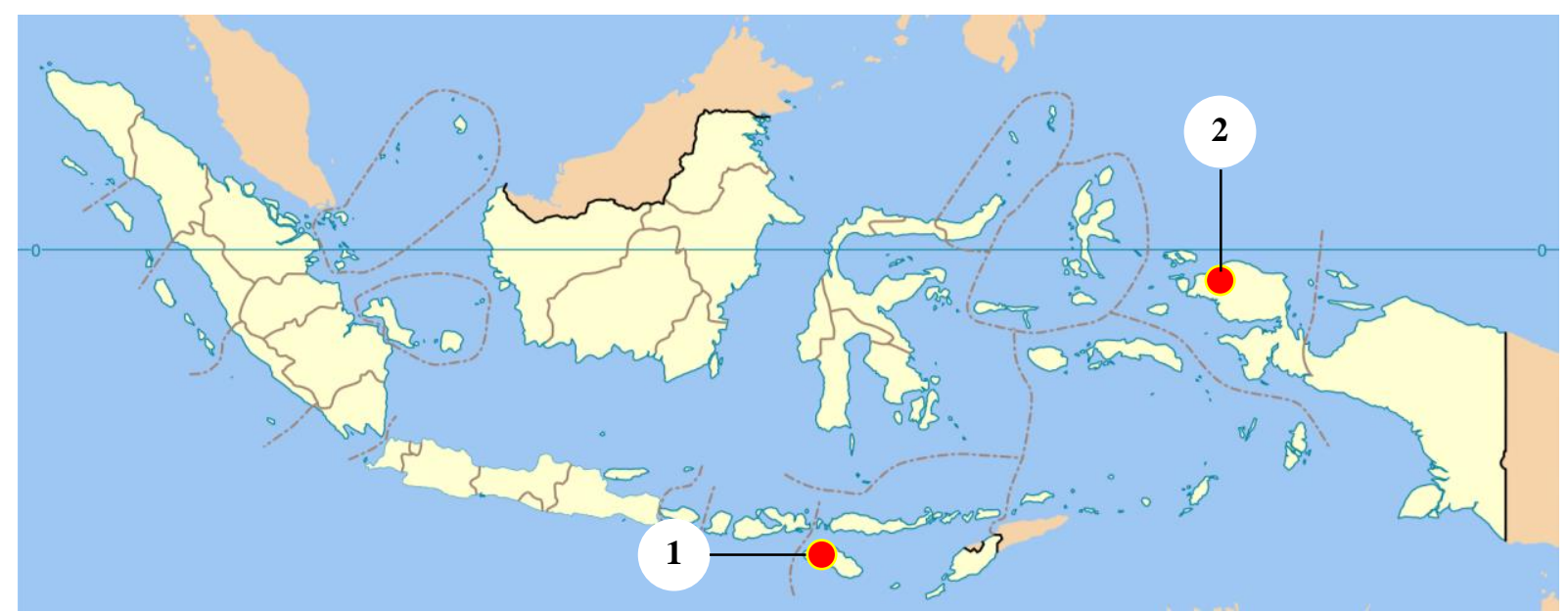

Figure 1. Map of Indonesia. The sampling areas in this study in: 1. Gaura Village, South West Sumba District of East Nusa Tenggara, Indonesia (October 2018); 2. Aimas, Sorong District of West Papua, Indonesia (August 2019) 
The thermal profile of 35 cycles for nested 1 was $94^{\circ} \mathrm{C}$ denaturation, $55^{\circ} \mathrm{C}$ annealings, and $72^{\circ} \mathrm{C}$ extensions, all at 1 minute each. That of nested 2 was $94^{\circ} \mathrm{C}$ denaturation $(30$ seconds), $55^{\circ} \mathrm{C}$ annealings ( 1 minute), and $72^{\circ} \mathrm{C}$ extensions (30 seconds). The entire reactions had $12.5 \mu \mathrm{l}$ volumes and contained $7 \mu \mathrm{l}$ PCR enzymes $(2 \times$ Taq plus PCR Mix, Tiangen Biotech), reverse and forward primers at $1 \mu \mathrm{l}$ each,

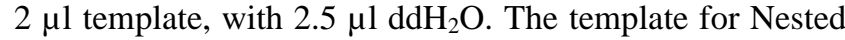
1 was the DNA, while that of 2 was its PCR results which were then run in $2 \%$ agarose gel for electrophoresis. After the Anopheles species were identified microscopically, their DNA was extracted and amplified by PCR ITS2 primer and then sequenced for confirmations.

\section{RESULTS AND DISCUSSION}

\section{Results}

A total of 1,336 mosquitoes were trapped using the Kelambu in two different islands, where the highest number of females was 843 in Aimas, but 493 in Gaura village. Furthermore, the total species in the samples was 28, 13 species of Anopheles and it was the largest species, followed by Culex (10), Armigeres (2), Aedes (2), and Lutzia (1).

In Gaura village, the commonest species was found is Anopheles (289), dominated by An. vagus, followed by Culex (153), Armigeres (49), Aedes (1), and Lutzia (1). The Culex genus dominated the mosquitoes trapped in the Aimas region, Sorong district (834 out of the 843), and the most numerous species was $C$. quinquefasciatus, while for Aedes and Anopheles, only 7 and 2 were caught, respectively.

From 285 mosquito pools (each containing 1-5 mosquitoes of the same species), one was positive for $P l$. falciparum, another for $P l$. vivax, and both were from the Anopheles sundaicus pools. The display of PCR electrophoresis result contained positive $P$. falciparum and $P l$. vivax can be seen in figure 2. From this study, it was found that one species of mosquito that acts as a malaria vector in Gaura Village, namely An. sundaicus, while in Aimas, Sorong District, malaria vectors were not found in all of 843 mosquitoes. This study was the first research conducted in malaria-endemic areas. In addition, after the Anopheles species sequencing process, we reported the first time that $A$. bailey species was found in Indonesia.

\section{Discussion}

One perspective regarding malaria transmission is accruing the number of vectors from other species, causing the disease's elimination to become difficult. Therefore this study was conducted to determine the vector of Plasmodium in malaria-endemic areas. It was known that mutation occurs in living organisms frequently due to the replication, transcription, and translation process (Lynch 2010; Campbell et al. 2015), and this affects the capability to widen or narrow the symbiosis between mosquito and its borne microbes. Particularly, there is the possibility that Anopheles is not the only host for Plasmodium. To ascertain whether a mosquito species is a vector, laboratory experiments were carried out by transfecting it with a certain microbe. However, the host's capacity to accept microorganisms is dependent on the evolution of these microbes (Duffy et al. 2012; Sheppard et al. 2018). The finding of new species that acts as a vector for Plasmodium explains why this disease remains prevalent and also creates the opportunity to control the transmission. As best known, identifying mosquito species other than Anopheles in malaria-endemic areas in Indonesia has never been done.

Table 1. The mosquito genera and species collected by Kelambu trap in housing residents and the total number of pools tested from Sumba and Sorong districts, Indonesia

\begin{tabular}{|c|c|c|c|c|}
\hline Area & Genera & Species & $\begin{array}{c}\text { No. of } \\
\text { mosquitoes } \\
\text { collected }\end{array}$ & $\begin{array}{c}\text { No. of pools } \\
\text { positive/ } \\
\text { no. of pools } \\
\text { tested }\end{array}$ \\
\hline \multicolumn{3}{|c|}{ Gaura, Anopheles An. vagus* } & 101 & $0 / 21$ \\
\hline \multirow[t]{26}{*}{ Sumba } & & An. sundaicus* & 53 & $2 / 11$ \\
\hline & & An. aconitus* & 18 & $0 / 5$ \\
\hline & & An. kochi & 15 & $0 / 3$ \\
\hline & & An. flavirostris* & 6 & $0 / 2$ \\
\hline & & An. indefinitus & 13 & $0 / 3$ \\
\hline & & An. maculatus* & 10 & $0 / 2$ \\
\hline & & An. minimus* & 7 & $0 / 2$ \\
\hline & & An. annularis* & 55 & $0 / 13$ \\
\hline & & An. nivipes* & 1 & $0 / 1$ \\
\hline & & An. subpictus & 10 & $0 / 2$ \\
\hline & & Sub total & 289 & $2 / 65$ \\
\hline & Culex & C. tritaeniorhyncus & 36 & $0 / 8$ \\
\hline & & C. fuscocephalus & 19 & $0 / 4$ \\
\hline & & C. sitiens sitiens & 4 & $0 / 1$ \\
\hline & & C. vishnui & 8 & $0 / 2$ \\
\hline & & C. gellidus & 1 & $0 / 1$ \\
\hline & & C. quinquefasciatus & 1 & $0 / 1$ \\
\hline & & C. whitei & 1 & $0 / 1$ \\
\hline & & C. hutchinsoni & 24 & $0 / 5$ \\
\hline & & C. pseudovishnui & 59 & $0 / 12$ \\
\hline & & Sub total & 153 & $0 / 35$ \\
\hline & Armigeres & Arm. kesseli & 22 & $0 / 5$ \\
\hline & & Arm. subalbatus & 27 & $0 / 6$ \\
\hline & & Sub total & 49 & $0 / 11$ \\
\hline & Aedes & Aedes $s p$ & 1 & $0 / 1$ \\
\hline & Lutzia & Lutzia sp & 1 & $0 / 1$ \\
\hline \multirow{12}{*}{$\begin{array}{l}\text { Aimas, } \\
\text { Sorong }\end{array}$} & Anopheles & An. baileyi $*$ & 1 & $0 / 1$ \\
\hline & & An. barbirostris* & 1 & $0 / 1$ \\
\hline & & Sub total & 2 & $0 / 2$ \\
\hline & Aedes & Ae. aegypti & 2 & $0 / 1$ \\
\hline & & Ae. Albopictus & 5 & $0 / 1$ \\
\hline & & Subtotal & 7 & $0 / 2$ \\
\hline & Culex & C. quinquefasciatus & 740 & $0 / 148$ \\
\hline & & C. bitaeniorhynchus & 63 & $0 / 13$ \\
\hline & & C. tritaeniorhynchus & 28 & $0 / 6$ \\
\hline & & C. gellidus & 3 & $0 / 1$ \\
\hline & & Subtotal & 834 & $0 / 168$ \\
\hline & & Totally & 1336 & Total: $2 / 285$ \\
\hline
\end{tabular}

Note: *Anopheles validated by PCR using ITS2 primer (Weeraratne et al. 2017) and sequenced to clarify the species 


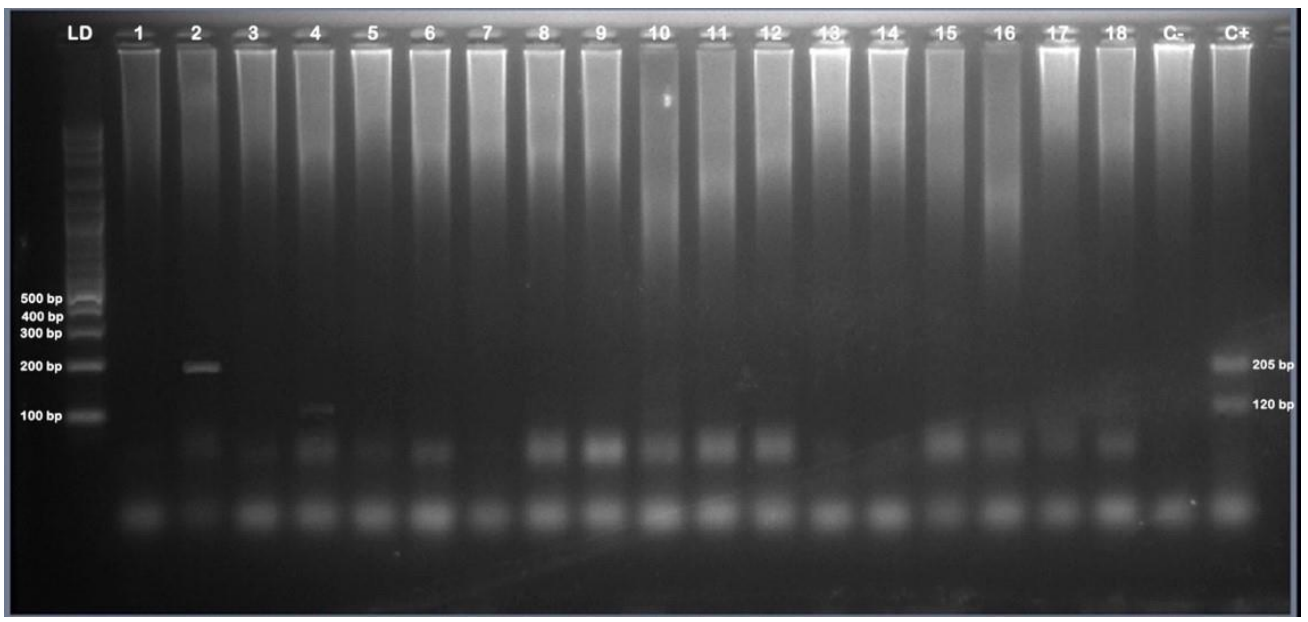

Figure 2. The result was based on electrophoresis of nested PCR mosquito samples. (LD: DNA ladder, C-: control negative, C+: control positive, 2: An. sundaicus for positive Plasmodium falciparum and 4: An. sundaicus for positive P. vivax). Also, there were $120 \mathrm{bp}$ (base pairs) for positive Plasmodium vivax and $205 \mathrm{bp}$ for positive $P$. falciparum

This study found that An. sundaicus was the vector of malaria in Gaura. As we know that An. sundaicus is an important vector for spreading malaria in Indonesia (Elyazar et al. 2013; Sugiarto et al. 2016). It has a habit of biting at dusk and dawn (Chakim and Pumpaibool 2019) and is generally found in coastal areas (Surendran et al. 2010). Furthermore, it sucks blood from humans (anthropophilic) and animals (Arifianto 2015), which allows them to breed quickly. In the last decades, $A n$. sundaicus has been reported as resistant to several insecticides (Silva et al. 2014; Raghavendra et al. 2017), which causes this species to survive longer. The contribution of mosquitoes to malaria transmission is influenced by environmental factors, blood-feeding, vector competence, season, and others. Overall, no vector other than Anopheles was detected as a Plasmodium host in this study. However, we also found differences between Gaura and Aimas (24 and 8 species, respectively). Environmental characteristics between the two villages seem responsible for those conditions. Compared to Aimas, people living in Gaura are more diverse because some live in Inland, coastal areas, and hills.

The Abundance of An. vagus found in Gaura village requires investigation into its possible contribution to malaria transmission in this village, considering An. vagus has been reported as a malaria vector in the South Sumatra region (Budiyanto et al. 2017). In this study An. vagus was captured outdoor. This allows the species to be protected from vector control programs such as Indoor Residual Spraying (IRS). Testing of Anopheles, Culex, Armigeres, Aedes vectors caught in malaria-endemic areas for the presence of Plasmodium may be helpful to confirm their role in malaria transmission.

Apart from COI, ITS2 primers are often used to differentiate Anopheles species because of their excellent accuracy. In this study, An. nivipes was found in West Sumba while An. baileyi and An. barbirostris were found in West Papua. From reports on the distribution and bionomics of Anopheles as a malaria vector, there are no reports of this species in that area. Anopheles nivipes has been reported in Sumatera while An. bailey in Thailand (Somboon et al. 2020). Furthermore, An. barbirostris is an essential vector for the spread of malaria in the country. However, this species has never been reported in West Papua, but only in Kalimantan (Indriyati et al. 2017), Sumatra (Yulidar 2017; Yahya et al. 2020), Java (Ndoen et al. 2010; Hastuti 2011) and Sulawesi (Pinontoan et al. 2017).

The detection of Plasmodium in mosquitoes was performed by placing 1-5 head-thorax from the same species in one pool for DNA analysis that allowed more amplification. Once it was detected, each abdomen of the vectors was molecularly examined to determine the number of species carrying parasites in the pool. This method reduces time and budget consumption, especially in a developing country where malaria is usually endemic.

Anopheles is the most suitable host for Plasmodium. However, the larvae's absence found in the survey during the malaria outbreak in Sorong district requires an explanation of whether the samples taken were less representative. Also, this is potentially due to other reasons, such as the existence of alternative vectors. The number of mosquitoes collected in this study indirectly affects the results. The more samples in detection, the better it will be in the future. Also, the inability to carry the nitrogen tank to the plane caused ten days collection time in each area to prevent mosquitoes' damage because they were placed at room temperature only.

\section{ACKNOWLEDGEMENTS}

We thank the local community for allowing their cows used as baits for mosquitoes and the safety provided during the collection at night. We also thank Nirwana Nur from Hasanuddin University Entomology Laboratory for the assistants rendered in detecting mosquito species and Handayani Halik from Hasanuddin University Medical Research Center (HUM-RC) for her assistance in molecular works. This study was funded by the Ministry of Research and Technology of the Republic of Indonesia. 


\section{REFERENCES}

Arifianto RP. 2015. Studi Bionomik Nyamuk Anopheles sundaicus Rodenwaldt di Desa Bangsring Kecamatan Wongsorejo Kabupaten Banyuwangi. [Essay]. Jember University, Jember. [Indonesian].

Berger D, Stanberg J, Grieshop K, Allibert IM. 2017. Temperature effects on life-history trade-offs, germline maintenance and mutation rate under simulated climate warming. Proc Biol Sci 284: 1-10. DOI 10.1098/rspb.2017.1721.

Budiyanto A, Ambarita LP, Salim M. 2017. Konfirmasi Anopheles sinensis dan Anopheles vagus sebagai vektor malaria di Kabupaten Muara Enim Provinsi Sumatera Selatan. Aspirator 9: 51-60. DOI 10.22435/aspirator.v9i2.5998.51-60. [Indonesian]

Campbell IM, Yuan B, Robberecht C, Pfundt R, Szafranski P, McEntagart ME, Nagamani SC, Erez A, Bartnik M, Wiśniowiecka-Kowalnik B Plunkett KS, Pursley AN, Kang SH, Bi W, Lalani SR, Bacino CA, Vast M, Marks K, Patton M, Olofsson P, Patel A, Veltman JA, Cheung SW, Shaw CA, Vissers LE, Vermeesch JR, Lupski JR, Stankiewicz P. 2014. Parental somatic mosaicism is underrecognized and influences recurrence risk of genomic disorders. Am J Hum Genet 95 (2): 173-82. DOI: 10.1016/j.ajhg.2014.07.003.

Campbell IM, Shaw CA, Stankiewicz P, Lupski JR. 2015. Somatic mosaicism: Implications for disease and transmission genetics. Trends Genet 31 (7): 382-392. DOI: 10.1016/j.tig.2015.03.013.

Chakim I, Pumpaibool T. 2019. The diversity of Anopheles blood feeding patterns suggests different malaria protection strategies in differen localities. F1000Res 8: 1217. DOI: 10.12688/f1000research.19341.4.

Davidson JR, Wahid I, Sudirman R, Makuru V, Hasan H, Arfah AM, Nur $\mathrm{N}$, Hidayat MY, Hendershot AL, Xiao H, Yu X, Asih PBS, Din Syafruddin D, Neil F. Lobo NF. 2019. Comparative field evaluation of kelambu traps, barrier screens and barrier screens with eaves for longitudinal surveillance of adult Anopheles mosquitoes in Sulawesi, Indonesia. Parasites Vectors 12 (1): 1-13. DOI: 10.1186/s13071-0193649-7.

Duffy MA, Ochs JH, Penczykowski RM, Civitello DJ, Klausmeier CA, Hall SR. 2012. Ecological context influences epidemic size and parasite-driven evolution. Sci 335: 1636-1638. DOI: $10.1126 /$ science. 1215429.

Elyazar IR, Sinka ME, Gething PW, Tarmidzi SN, Surya A, Kusriastuti R, Winarno, Baird JK, Hay SI, Bangs MJ. 2013. The distribution and bionomics of Anopheles malaria vector mosquitoes in Indonesia. Adv Parasitol 83: 173-266. DOI: 10.1016/B978-0-12-407705-8.00003-3.

Indriyati L, Sembiring WSR, Rosanji A. 2017. Keanekaragaman Anopheles Spp di Daerah Endemis Malaria Desa Siayuh (Trans) Kabupaten Kotabaru Provinsi Kalimantan Selatan. ASPIRATOR 9: 11-20. DOI: 10.22435/aspirator.v9i1.4979.11-20. [Indonesian]

Ministry of Health of the Republic of Indonesia. 2014. Pusat Data dan Informasi Kementerian Kesehatan RI. Infodatin Kemenkes, Jakarta [Indonesian]

Ministry of Health of the Republic of Indonesia. 2016. Malaria. Infodatin Kemenkes, Jakarta. [Indonesian]

Lynch M. 2010. Evolution of the mutation rate. Trends Genet 26 (8): 345 352. DOI: 10.1016/j.tig.2010.05.003

McDew-White M, Li X, Nkhoma SC, Nair S, Cheeseman I, Anderson TJC. 2019. Mode and tempo of microsatellite length change in malaria parasite mutation accumulation experiment. Genome Biol Evol 11 (7): 1971-1985. DOI: 10.1093/gbe/evz140.

Mackinnon MJ, Marsh K. 2010. The selection landscape of malaria parasites. Sci 328: 866-871. DOI: 10.1126/science.1185410.

M'Gonigle LK, Shen JJ, Otto SP. 2009. Mutating away from your enemies: The evolution of mutation rate in a host-parasite system. Theor Popul Biol 75 (4): 301-311. DOI: 10.1016/j.tpb.2009.03.003.

Mills JN, Gage KL, Khan AS. 2010. Potential influence of climate change on vector-borne and zoonotic diseases: A review and proposed research plan. Environ Health Perspect 118 (11): 1507-1514. DOI: 10.1289/ehp.0901389.

Ndoen E, Wild C, Dale P, Sipe N, Dale M. 2010. Relationships between anopheline mosquitoes and topography in West Timor and Java, Indonesia. Malar J 9: 242. DOI: 10.1186/1475-2875-9-242.

Nurdin A, Syafruddin D, Wahid I, Noor NN, Sunahara T, Mogi M. 2003. Malaria and Anopheles spp in the villages of Salubarana and Kadaila, Mamuju District, South Sulawesi Province, Indonesia. Med J Indones 12 (4): 252-258. DOI: $10.13181 /$ mji.v12i4.119

Ogoma SB, Lweitoijera DW, Ngonyani H, Furer B, Russell TL Mukabana WR, Killeen GF, Moore SJ. 2010. Screening mosquito house entry points as a potential method for integrated control of endophytic filariasis, arbovirus and malaria vectors. PLoS Negl Trop Dis 4 (8): e773. DOI: 10.1371/journal.pntd.0000773.

PATH Malaria Center of Excellence. 2014. Transformative Tools for Malaria Elimination. Available from Center for Strategic \& International Studies, Washington DC.

Pinontoan OR, Supadmanaba IGP, Manuaba IBA, Sukrama IDM, Manuaba IBP. 2017. Local diversity and biting pattern of Anopheles species in Southern Minahasa. Interdiscip Perspect Infect Dis 2017: 16. DOI: $10.1155 / 2017 / 6313016$.

Raghavendra K, Velamuri PS, Verma V, Elamathi N, Barik TK, Bhatt RM, Dash AP. 2017. Temporo-spatial distribution of insecticideresistance in Indian malaria vectors in the last quarter-century: Need for regular resistance monitoring and management. J Vector Borne Dis 54 (2): 111-130.

Sheppard SK, Guttman DS, Fitzgerald JR. 2018. Population genomics of bacterial host adaptation. Nat Rev Genet 19 (9): 549-565. DOI: 10.1038/s41576-018-0032-z.

Singh B, Daneshvar C. 2013. Human infections and detection of Plasmodium knowlesi. Clin Microbiol Rev 26: 165-184. DOI: 10.1128/CMR.00079-12

Sinka ME, Bangs MJ, Manguin A, Rubio-Palis Y, Chareonviriyaphap T, Coetzee M, Mbogo CM, Hemingway J, Patil AP, Temperley WH, Gething PW, Kabaria CW, Burkot TR, Harbach RE, Hay SI. 2012. A global map of dominant malaria vector. Parasites Vectors 5: 69.

Silva AP, Santos JM, Martins AJ. 2014. Mutations in the voltage-gated sodium channel gene of anophelines and their association with resistance to pyrethroids - a review. Parasites Vectors 7: 450. DOI: 10.1186/1756-3305-7-450.

Snounou, G., Viriyakosol, S., Zhu, X. P., Jarra, W., Pinheiro, L., Do Rosario, V. E., et al. (1993) High sensitivity of detection of human malaria parasites by the use of nested polymerase chain reaction. Mol. Biochem. Parasitol.61, 315-320. DOI: 10.1016/0166-6851(93)90077-b

Somboon P, Phanitchakun T, Namgay R, Wangdi T, Pemo D, Harbach RE. 2020. Molecular and morphological evidence of sibling species in Anopheles baileyi Edwards (Diptera: Culicidae) in Bhutan and Thailand. Acta Trop 209: 105549. DOI: 10.1016/j.actatropica.2020.105549.

St. Laurent B, Supratman S, Asih PBS, Bretz D, Mueller J, Miller HC, Baharuddin A, Shinta, Surya A, Ngai M, Laihad F, Syafruddin D, Hawley WA, Collins FH, Lobo NF. 2016. Behaviour and molecular identification of Anopheles malaria vectors in Jayapura district, Papua province, Indonesia. Malar J 15: 192. DOI: 10.1186/s12936-016-1234-5.

Sugiarto, Hadi KU, Soviana S, Hakim L. 2016. Confirmation of Anopheles peditaeniatus and Anopheles sundaicus as Malaria Vectors (Diptera: Culicidae) in Sungai Nyamuk Village, Sebatik Island North Kalimantan, Indonesia Using an Enzyme-Linked Immunosorbent Assay. J Med Entomol 53 (6): 1422-1424. DOI: 10.1093/jme/tjw100.

Surendran SN, Singh OP, Jude PJ, Ramasamy R. 2010. Genetic evidence for malaria vectors of the Anopheles sundaicus complex in Sri Lanka with morphological characteristics attributed to Anopheles subpictus species B. Malar J 9: 343. DOI: 10.1186/1475-2875-9-343.

Veridiana NN, Chadijah S, Srikandi Y, Octaviani O. 2019. Konfirmasi vektor malaria dengan elisa di daerah Mendui, Kec. Bungku Tengah, Kab. Morowali, Sulawesi Tengah. Jurnal Vektor Penyakit 3 (1): 2631. [Indonesian]

Weeraratne TC, Surendran SN, Reimer LJ, Wondji CS, Perera MDB, Walton C, Karunaratne SHPP. 2017. Molecular characterization of Anopheline (Diptera: Culicidae) mosquitoes from eight geographical locations of Sri Lanka. Malar J 16: 1-14. DOI: 10.1186/s12936-0171876-y

World Health Organization (WHO). 2013. Global Program to Eliminate Lymphatic Filariasis. WHO, Italy.

World health organization (WHO). 2019. Malaria. (accessed October 18, 2019). https://www.who.int/news-room/fact-sheets/detail/malaria.

Yahya, Haryanto D, Pahlepi RI, Budiyanto A. 2020. Keanekaragaman jenis nyamuk Anopheles di sembilan kabupaten (tahap pre-eliminasi malaria) di Provinsi Sumatera Selatan. Vektora 12: 41-52. [Indonesian]

Yulidar. 2017. Survei nyamuk Anopheles yang diduga berpotensi sebagai vektor malaria di Kabupaten Aceh Besar. Jurnal Biologi Edukasi 9 (1): 1-5. [Indonesian] 